\title{
A polar extract of the Maya healing plant Anthurium schlechtendalii (Aracea) exhibits strong in vitro anticancer activity
}

\author{
NICOLE STARK $^{1}$, MANUELA GRIDLING $^{1}$, SIBYLLE MADLENER ${ }^{1}$, SABINE BAUER $^{1}$, ANDREAS LACKNER $^{2}$, \\ RUXANDRA POPESCU ${ }^{3}$, RENE DIAZ ${ }^{4}$, FOSTER M. TUT ${ }^{4}$, THANH-PHUONG NHA VO ${ }^{1,5}$, CAROLINE VONACH $^{1}$, \\ BENEDIKT GIESSRIGL ${ }^{1}$, PHILIPP SAIKO ${ }^{6}$, MICHAEL GRUSCH ${ }^{2}$, MONIKA FRITZER-SZEKERES ${ }^{6}$, \\ THOMAS SZEKERES ${ }^{6}$, BRIGITTE KOPP ${ }^{3}$, RICHARD FRISCH ${ }^{4}$ and GEORG KRUPITZA ${ }^{1}$

\begin{abstract}
${ }^{1}$ Institute of Clinical Pathology, Medical University of Vienna, Waehringer Guertel 18-20; ${ }^{2}$ Department of Medicine I, Institute of Cancer Research, Medical University of Vienna, Borschkegasse 8a; ${ }^{3}$ Department of Pharmacognosy, Faculty of Life Sciences, University of Vienna, Althanstrasse 14, Austria; ${ }^{4}$ Institute for Ethnobiology, Playa Diana, San José/Petén, Guatemala; ${ }^{5}$ Department of Pharmaceutical Chemistry, Faculty of Life Sciences, University of Vienna, Althanstrasse 14; ${ }^{6}$ Department of Medical and Chemical Laboratory Diagnostics, Medical University of Vienna, Waehringer Guertel 18-20, Austria
\end{abstract}

Received March 30, 2009; Accepted May 15, 2009

DOI: 10.3892/ijmm_00000260

\begin{abstract}
The Aracea Anthurium schlechtendalii and Syngonium podophyllum are traditional remedies for the treatment of severe and chronic inflammatory conditions. We cross-examined these plants regarding their anti-neoplastic properties, because several anti-inflammatory molecular targets are common for both pathologic conditions due to similar signalling pathways. Two malignant cell lines, HL-60 and MCF-7, were treated with increasing concentrations of plant extracts of increasing polarity. The potential of the extracts to inhibit the cell cycle and to induce cell death was investigated, because these are relevant endpoints to assess the anti-cancer potential in vitro and the protein expression and cell cycle distribution upon exposure to the strongest extract was analysed. Extracts from $S$. podophyllum were rather ineffective, but the freeze-dried (but not air-dried) roots of A. schlechtendalii exhibited strong growth inhibitory and apoptosis-inducing properties. In HL-60 cells 50\% proliferation inhibition was achieved by $1.7 \mu \mathrm{g}$ dichloromethane extract $/ \mathrm{ml}$ medium and correlated with the activation of Chk2, down-regulation of Cdc25A, suppression of cyclin D1 level, and transient induction of p21. This extract efficiently triggered apoptosis, which was confirmed by caspase 3 activation. The polymerisation of $\alpha$-tubulin and its
\end{abstract}

Correspondence to: Professor Georg Krupitza, Institute of Clinical Pathology, Medical University of Vienna, Waehringer Guertel 18-20, A-1090 Vienna, Austria

E-mail: georg.krupitza@meduniwien.ac.at

Key words: Anthurium schlechtendalii, polar extract, anti-cancer, ethnopharmacology subsequent degradation that depleted the cells from the G2/M contributed to apoptosis induction, because proper spindleformation during mitosis is mandatory for survival. In conclusion, we demonstrated that A. schlechtendalii root extract specifically targeted carcinogenic mechanisms, because Cdc25A and cyclin D1 are oncogenes that are frequently overexpressed in a variety of cancer entities and further, this extract affected microtubule function reminiscent of taxol.

\section{Introduction}

More than $90 \%$ of the medications used in the non-industrialised world are natural products and over $60 \%$ of the lead compounds of the drugs used in Western medicine have their origin in plants and microbes (1). Therefore, the biosphere is still screened at random to discover new leads. Another approach, which is highly focussed and saves from a high rate of unsuccessful 'tries and errors' of broad spectrum screening and offers a high probability to find new lead compounds against cancer requests the ancient ethno-botanical knowledge of traditional medicines. This knowledge is based on in-depth and long lasting empirical experience in locally available natural resources - mainly plants. The North American tribe of the Quinault treated (treats) stomach and kidney complaints with the bark of the evergreen Pacific yew tree (Taxus brevifolia), and a pharmaceutical company isolated Taxol from this plant bark and developed paclitaxel for the treatment of breast cancer.

Plant toxins provide an evolutionary advantage, because bioactive compounds play a role in defence mechanisms e.g. against grazing, fungal bacterial or viral intrusions. An important feature of currently used anticancer drugs is their high toxicity that triggers programmed cell death (apoptosis) and/or their potential to inhibit cell cycle progression. 
To discover new anticancer remedies from ethno-medicinal plants we searched for anti-inflammatory remedies used by the Maya of the El-Peten/Belize lowland rainforests because they still practice their traditional medicine that is based on the extremely rich biodiversity of this tropical area (2). However, preventive- or even therapeutic remedies against cancer are unknown in ancient medicinal concepts, because, in general, those civilisations or communities did not live long enough to obtain a substantial experience with this disease that mostly occurs late in age. Yet, they are well aware of all kinds of inflammations and severe skin conditions. In tumour cells several pathways are induced that may also be activated in inflamed tissues e.g. MEK-Erk, COX-2 and NF-кB/Rel (3-6). We selected two anti-inflammatory and well tolerated healing plants that are still used by the Maya to study their anticancer activity. Here we describe the bio-activity of extracts of $S$. podophyllum and A. schlechtendalii (both from the Aracea family) in HL-60 promyeloic leukaemia and MCF-7 breast cancer cells.

\section{Materials and methods}

Plant material. Leaves and roots of Anthurium schlechtendalii and the aerial parts of Syngonium podophyllum were collected in Playa Diana, San José/Petén, Guatemala, in August, 2006, and identified by Dr Richard Frisch of the Institute of Ethnobotany, San Jose, El-Petén, Guatemala. Voucher specimens were deposited in the Herbarium of the Institute of Ethnobotany, Playa Diana, San José, El-Petén.

Extraction. Of the species A. schlechtendalii, $50.1 \mathrm{~g}$ air-dried foliage- and $50.0 \mathrm{~g}$ air-dried root material, and $32.6 \mathrm{~g}$ freezedried foliage- and $32.1 \mathrm{~g}$ freeze-dried root material, and of $S$. podophyllum $43.8 \mathrm{~g}$ air-dried, and $51.6 \mathrm{~g}$ freeze-dried aerial plant part material were ground and successively extracted with petroleum ether, dichloromethane, ethyl acetate and methanol (500 $\mathrm{ml}$ each). The extracts were evaporated under vacuum and the residues were dissolved in $2 \mathrm{ml}$ ethanol for testing in HL-60 and MCF-7 cells. For the proliferationand apoptosis analyses following concentrations were used: $500 \mu \mathrm{g} / \mathrm{ml}, 1 \mathrm{mg} / \mathrm{ml}, 4 \mathrm{mg} / \mathrm{ml}, 20 \mathrm{mg} / \mathrm{ml}$, as well as $0.2 \%$ $\mathrm{EtOH}$ solvent control. Forty $\mathrm{mg} / \mathrm{ml}$ was the concentration in which the extract remained dissolved when added to the cell culture medium but exhibited non-specific toxicity inducing necrosis (data not shown). Therefore, we used only $20 \mathrm{mg} / \mathrm{ml}$ as the highest tested concentration.

Reagents and antibodies. Hoechst 33258 and propidium iodide were purchased from Sigma. ECL Western blotting Substrate Cat\# 32106 was from Pierce. Antibodies: mouse monoclonal anti-acetylated tubulin clone 6-11B1 Cat\# T6793, and mouse monoclonal anti- $\beta$-actin clone AC-15 Cat\# A5441, were from Sigma. Mouse monoclonal anti-cdc25A (F-6) Cat\# 7389, anti- $\alpha$-tubulin (TU-02) Cat\# sc-8035, PARP-1 (F-2) Cat\# sc-8007, and anti-cyclin D1 (M-20) Cat\# sc-718 were from Santa Cruz, anti-phospho-Cdc25A (Ser177; cl RB7637) Cat\# SA060424C was from Abgent. Rabbit monoclonal anti-active caspase-3 (CPP32) clone C92-605 Cat\# 58404 was from Research Diagnostics Inc. Polyclonal, anti-phospho-Chk2 (Thr68) Cat\#2661, anti-Chk2 Cat\# 2662,
anti-MEK 1/2 Cat\# 9122, polyclonal anti-phospho-MEK 1/2 (Ser 217/221) Cat\# 9121m, monoclonal rabbit anti-p44/42 MAP Kinase (Erk1/2; 137F5) Cat\# 4695, and mouse monoclonal anti-phospho-p44/42 MAPK (Erk1/2-Thr202/Tyr204) (E10) Cat\# 9106 were from Cell Signaling. Anti-mouse IgG was from Dako and anti-rabbit IgG and high performance chemiluminescence film was from GE Healthcare.

Cell culture. HL-60 promyelocytic leukemia-, and MCF-7 breast cancer cells were from ATCC. Cells were grown in RPMI-1640 (HL-60) or DMEM (MCF-7) medium supplemented with $10 \%$ heat inactivated fetal calf serum, $1 \% \mathrm{~L}$ glutamine and $1 \%$ penicillin/streptomycin at $37^{\circ} \mathrm{C}$ in a humidified atmosphere containing $5 \% \mathrm{CO}_{2}$. All media and supplements were obtained from Life Technologies.

Proliferation inhibition analysis. To determine the antiproliferative effect of the plant extracts HL-60 cells were seeded in T-25 tissue culture flasks at a concentration of $1 \times 10^{5}$ cells per ml. MCF-7 cells were seeded at a concentration of $1 \times 10^{4}$ cells per $\mathrm{ml}$ in 24-well plates and grown for $24 \mathrm{~h}$. Then, they were incubated with increasing extract concentration (corresponding to $500 \mu \mathrm{g} / \mathrm{ml}, 1 \mathrm{mg} / \mathrm{ml}, 4 \mathrm{mg} / \mathrm{ml}$ and $20 \mathrm{mg} / \mathrm{ml}$ dried plant) for $72 \mathrm{~h}$. After 24 and $72 \mathrm{~h}$ cells were counted with a micro-cell counter and $\mathrm{IC}_{50}$ values calculated. MCF-7 were trypsinised before counting. Experiments were done in triplicate. The percent of cell divisions compared to the untreated control were calculated as follows: $\left[\left(\mathrm{C}_{72 \mathrm{~h}+\mathrm{drug}}-\right.\right.$ $\left.\left.\mathrm{C}_{24 \mathrm{~h}+\text { drug }}\right) /\left(\mathrm{C}_{72 \mathrm{~h} \text { - drug }}-\mathrm{C}_{24 \mathrm{~h} \text { - drug }}\right)\right] \mathrm{x} 100=\%$ cell division; $\mathrm{C}$, cell number.

Cell death analysis. Hoechst 33258 propidium iodide double staining of the DNA was performed according to the method described (7). HL-60 cells $\left(1 \times 10^{5}\right.$ per $\left.\mathrm{ml}\right)$ were seeded in T-25 Nunc tissue culture flask and exposed to increasing concentrations of plant extracts $(500 \mu \mathrm{g} / \mathrm{ml}, 1 \mathrm{mg} / \mathrm{ml}, 4 \mathrm{mg} / \mathrm{ml}$ and $20 \mathrm{mg} / \mathrm{ml}$ ) for $48 \mathrm{~h}$. MCF-7 cells were seeded at a density of $1 \times 10^{4}$ cells per $\mathrm{ml}$ in 24-well plates and grown for $24 \mathrm{~h}$. Then, increasing concentrations of extract were added and the cells were treated for $96 \mathrm{~h}$. Then the cells were washed with PBS, treated with trypsin and resuspended with medium. Hoechst 33258 and propidium iodide were added directly to the cells at final concentrations of 5 and $2 \mu \mathrm{g} / \mathrm{ml}$, respectively. After $60 \mathrm{~min}$ of incubation at $37^{\circ} \mathrm{C}$, the apoptotic nuclear morphology of cells was examined with a Zeiss Axiovert fluorescence microscope and a DAPI filter. This method allows to distinguish between apoptosis and necrosis (8).

Western blotting. HL-60 cells $\left(1.5 \times 10^{7}\right)$ were seeded into T-75 Nunc tissue culture flasks and incubated with $27.9 \mu \mathrm{g} / \mathrm{ml}$ dichloromethane extract of $A$. schlechtendalii (corresponding to $4 \mathrm{mg} / \mathrm{ml}$ dried plant) for $0.5,2,4,8$ and $24 \mathrm{~h}$. Then $1 \times 10^{6}$ cells were harvested (per experimental point), washed twice with ice cold PBS, centrifuged at 1,000 rpm for $5 \mathrm{~min}$, lysed in a buffer containing $150 \mathrm{mM} \mathrm{NaCl}, 50 \mathrm{mM}$ Tris $\mathrm{pH} 8.0,1 \%$ Triton-X-100, $1 \mathrm{mM}$ phenylmethylsulfonylfluoride (PMSF) and Protease Inhibitor Cocktail (PIC; from a x100 stock). Then, the lysate was centrifuged at $12,000 \mathrm{rpm}$ for $20 \mathrm{~min}$ at $4^{\circ} \mathrm{C}$, and the supernatant was stored at $-20^{\circ} \mathrm{C}$ until further analysis. Equal amounts of protein samples were separated 
by polyacrylamide gel electrophoresis (PAGE) and electrotransferred onto PVDF-membranes (Hybond, Amersham) at $4^{\circ} \mathrm{C}$ overnight. Equal sample loading was controlled by staining membranes with Ponceau S. After washing with phosphate buffered saline/Tween-20 (PBS/T) pH 7.2 or Tris buffered saline/Tween-20 (TBS/T) pH 7.6, membranes were blocked for $1 \mathrm{~h}$ in blocking solution (5\% non-fat dry milk in PBS containing $0.5 \%$ Tween-20 or in TBS containing $0.1 \%$ Tween-20). Then, membranes were incubated with the first antibody (in blocking solution, dilution 1:500-1:1000) by gently rocking at $4^{\circ} \mathrm{C}$, overnight. Thereafter, the membranes were washed with PBS or TBS and further incubated with the second antibody (peroxidase-conjugated goat anti-rabbit IgG or anti-mouse IgG, dilution 1:2000-1:5000 in PBS/T or TBS/T) for $12 \mathrm{~h}$. Chemiluminescence was developed by the ECL detection kit (Pierce) and then membranes were exposed to high performance chemiluminescence film.

FACS analysis. HL-60 cells $\left(1 \times 10^{6}\right.$ per $\left.\mathrm{ml}\right)$ were seeded in $\mathrm{T}-25$ Nunc tissue culture flasks and incubated with 1.75 and $3.5 \mu \mathrm{g} / \mathrm{ml}$ dichloromethane extract (corresponding to 250 and $500 \mu \mathrm{g} / \mathrm{ml}$ freeze-dried A. schlechtendalii root) for $24 \mathrm{~h}$ under cell culture conditions. Then, cells were washed with $5 \mathrm{ml}$ cold PBS, centrifuged (800 rpm for $5 \mathrm{~min}$ ), and resuspended and fixed in $3 \mathrm{ml}$ cold ethanol $(70 \%)$ for $30 \mathrm{~min}$ at $4^{\circ} \mathrm{C}$. After two further washing steps with cold PBS, RNAse A, and propidium iodide were added to a final concentration of $50 \mu \mathrm{g} / \mathrm{ml}$ each and incubated at $4^{\circ} \mathrm{C}$ for $60 \mathrm{~min}$ before measurement. Cells were analysed on a FACSCalibur flow cytometer (BD Biosciences, San Jose, CA, USA) and cell cycle distribution was calculated with ModFit LT software (Verity Software House, Topsham, ME, USA).

Statistics. All experiments were done in triplicate and analysed by t-test (GraphPad Prism 4.0 program).

\section{Results}

The aerial parts of $S$. podophyllum are green except tiny hold-fast roots facilitating tree climbing and they were used without subdividing them in foliage, stem axis and roots. $A$. schlechtendalii is another member of the Aracea family in this tropical region and stemless. This plant was divided in roots and leaves. Both plants were tested as air-dried- (traditional way), and freeze-dried material (lyophilised) to avoid the degradation of labile bioactive metabolites.

Anti-proliferative activity of S. podophyllum extracts. All extracts inhibited HL-60 cell growth at the concentration of $20 \mathrm{mg} / \mathrm{ml}$ (mg dried plant weight $/ \mathrm{ml}$ cell culture medium, Fig. 1). The methanol extract was most effective with an $\mathrm{IpC}_{50}$ of $2.6 \mathrm{mg} / \mathrm{ml}$. The growth-inhibitory activities of the air dried material and the freeze dried material were rather similar.

Anti-proliferative activity of A. schlechtendalii extracts. Such as $S$. podophyllum also A. schlechtendalii extracts inhibited HL-60 cell growth. From the foliage the strongest growth inhibitory activity was contained in the dichloromethane extract derived from air dried material $\left(\mathrm{IpC}_{50}=6.7 \mu \mathrm{g}\right.$ dried extract weight corresponding to $0.5 \mathrm{mg}$ dried plant

\section{S. podophyllum aerial parts}

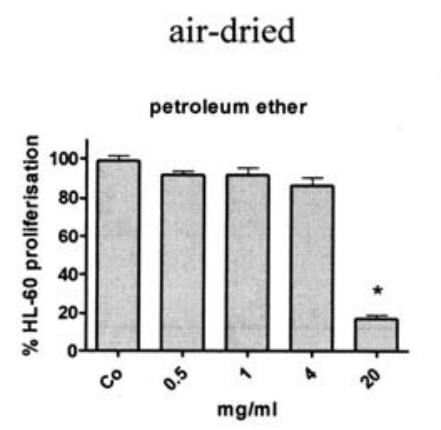

freeze-dried
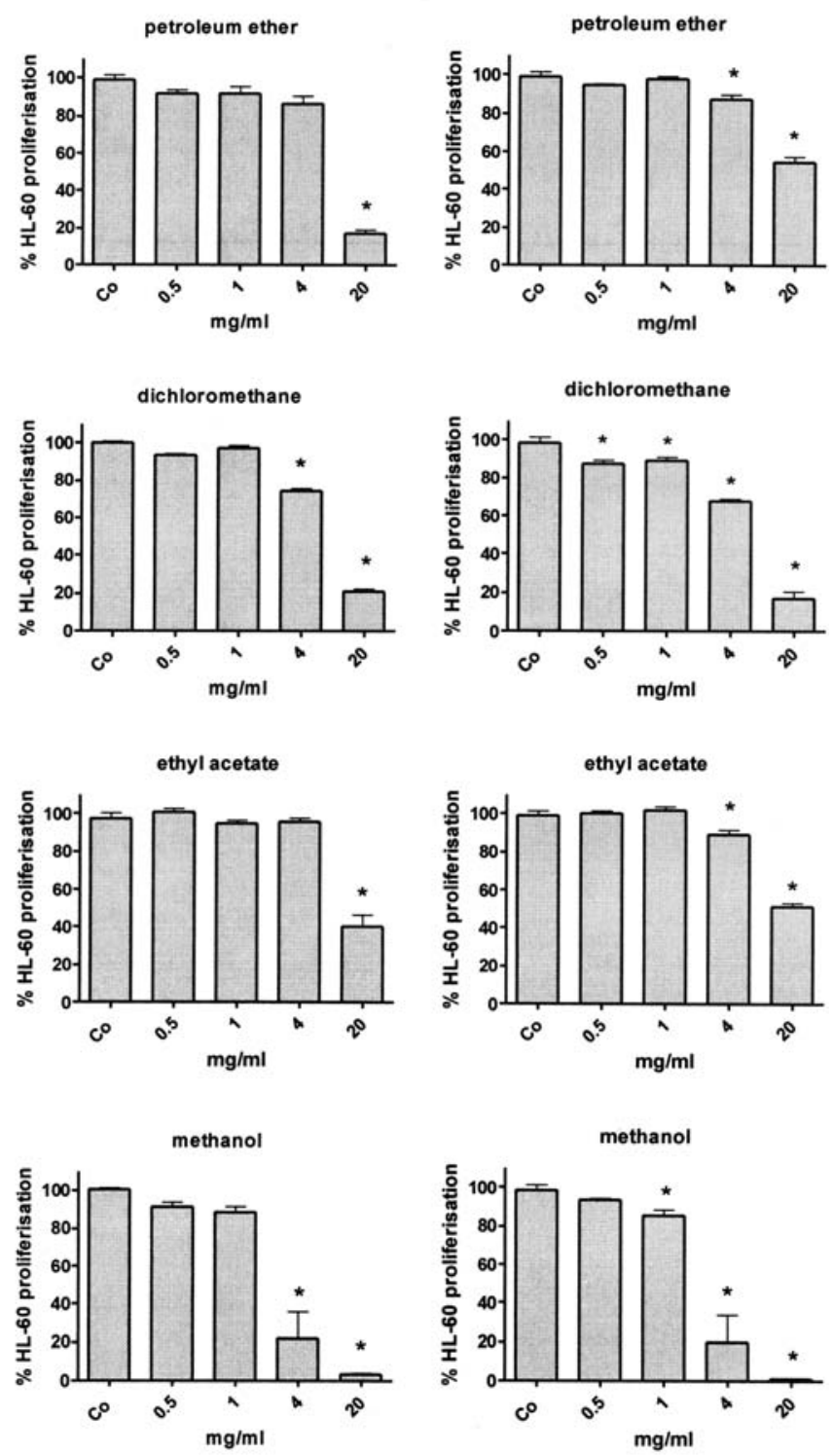

Figure 1. Anti-proliferative effects of air-dried and freeze-dried S. podophyllum. HL-60 cells were seeded into T-25 tissue culture flasks ( $1 \times 10^{5}$ cells $\left./ \mathrm{ml}\right)$, grown for $24 \mathrm{~h}$ to enter logarithmic growth phase, and incubated with the indicated extracts (petrol ether, dichloromethane, ethyl acetate and methanol) from $0.5,1,4$ and $20 \mathrm{mg} / \mathrm{ml}$ dried plant material. Controls received $0.2 \%$ EtOH which was the concentration cells had to experience together with the highest extract concentration. Cells were counted after 24, 48 and $72 \mathrm{~h}$ of treatment and the percentage of proliferation within this time span was calculated. Experiments were done in triplicate. Error bars indicate SEM, and asterisks significance $(\mathrm{p}<0.05)$.

weight/ml cell culture medium; Fig. $2 \mathrm{a}$ ), whereas the most potent growth inhibitory activity from roots was found in the dichloromethane extract of freeze-dried material $\left(\mathrm{IpC}_{50}=\right.$ $1.7 \mu \mathrm{g}$ dried extract weight corresponding to $0.25 \mathrm{mg}$ dried plant weight $/ \mathrm{ml}$ cell culture medium; Fig. 2b). Interestingly, freeze-dried leaves exhibited the growth-inhibitory activity only in the highest tested concentration, which suggested that the active principle was generated throughout the extended drying process (in the tropical climate). In contrast, the roots 

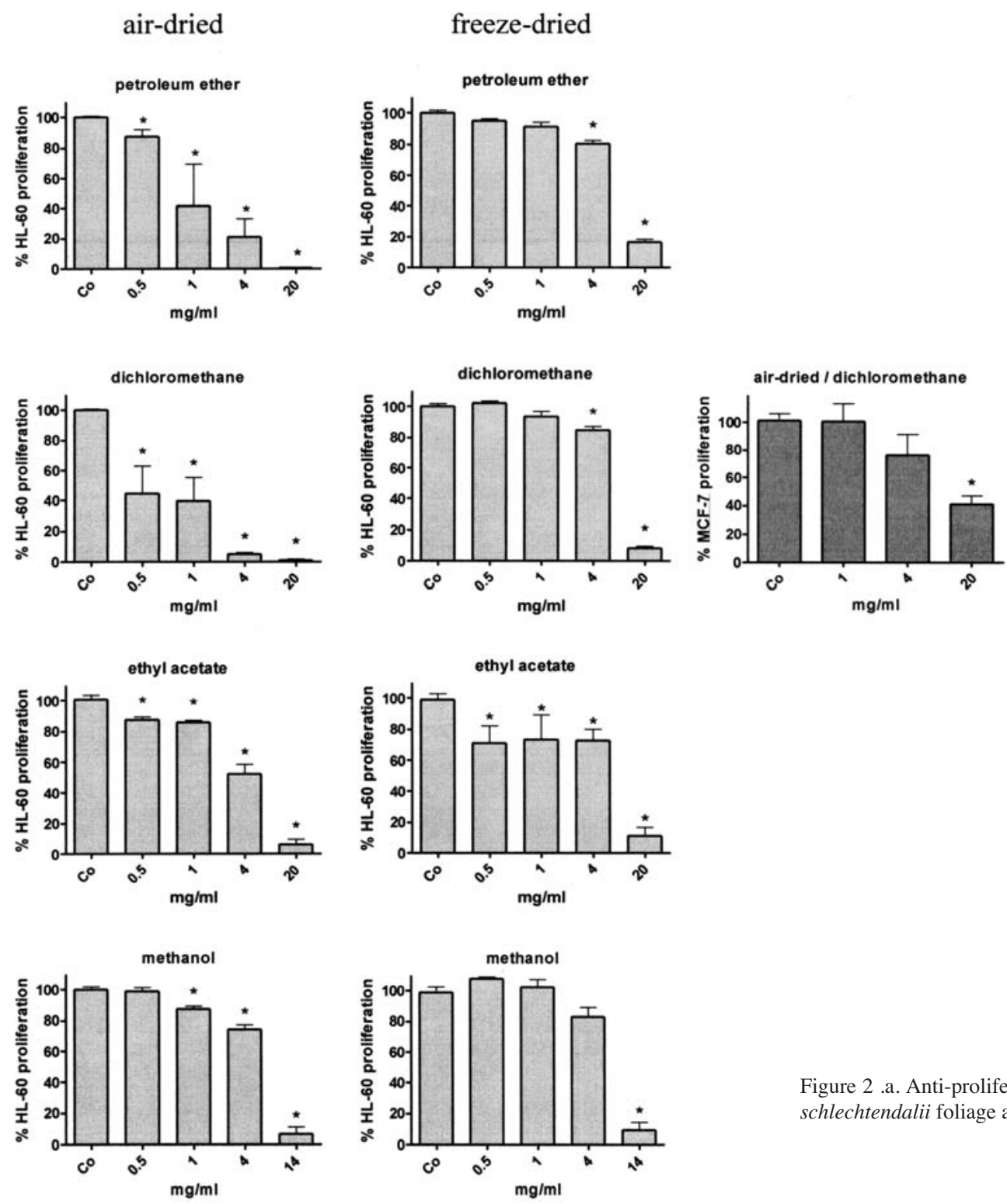

Figure 2 .a. Anti-proliferative effect of $A$. schlechtendalii foliage and root extracts.

lost their activity during air-drying implicating that the active principle in this plant part was different from that in the leaves and very unstable. The ethyl acetate and methanol root extracts (derived form freeze-dried plants) were slightly less active than the dichloromethane extract, which was therefore, used for further analyses.

Selected extracts were also tested in MCF-7 breast cancer cells, because MCF-7 cells were found to detect the vast majority of those agents which exhibit anticancer activity in the 60 cancer cell line screen of the National Cancer Institute (NCI) $(9,10)$. The dichloromethane extract of air-dried foliage inhibited MCF-7 cell proliferation only at a high concentration $\left(\mathrm{IpC}_{50}=236.3 \mu \mathrm{g}\right.$ dried extract weight corresponding to $17.5 \mathrm{mg}$ dried plant weight $/ \mathrm{ml}$ cell culture medium; Fig. 2a), whereas the freeze-dried root extract inhibited $50 \%$ of MCF-7 growth at a concentration that was in the same range as observed in HL-60 cells $\left(\mathrm{IpC}_{50}=4.1 \mu \mathrm{g}\right.$ dried extract weight corresponding to $0.6 \mathrm{mg}$ dried plant weight $/ \mathrm{ml}$ cell culture medium; Fig. 2b).
Modulated expression of cell cycle regulators. The freezedried dichloromethane root extract of A. schlechtendalii inhibited the cell cycle of HL-60 cells, which were incubated for $24 \mathrm{~h}$ with $1.75-3.5 \mu \mathrm{g} / \mathrm{ml}$ extract (corresponding to 250 and $500 \mu \mathrm{g} / \mathrm{ml}$ root), in S-phase depleting the cells from the G2/M phase (Fig. 3a). Typically, anticancer agents inhibit cancer cell growth by activating cell cycle check points such as p53, induce cell cycle inhibitors i.e. p21, interfere with $\mathrm{Cdk}$ activity or inhibit other mechanisms relevant for cell division such as the limited availability of nucleotides or disrupted cell segregation. Since HL-60 cells are p53-deficient the extract did not activate this surveillance mechanism. However, checkpoint kinase 2 (Chk2) was activated within $24 \mathrm{~h}$. A target site of Chk2 is serine 177 (Ser177) of the cell cycle protagonist $\mathrm{Cdc} 25 \mathrm{~A}$. In fact, this site was strongly phosphorylated (resulting in the inactivation of $\mathrm{Cdc} 25 \mathrm{~A}$ ), however, it is unlikely that this was by virtue of Chk2, because maximal Ser177-Cdc25A phosphorylation was already observed after $2 \mathrm{~h}$ of exposition to $27.9 \mu \mathrm{g} / \mathrm{ml}$ extract (corresponding 

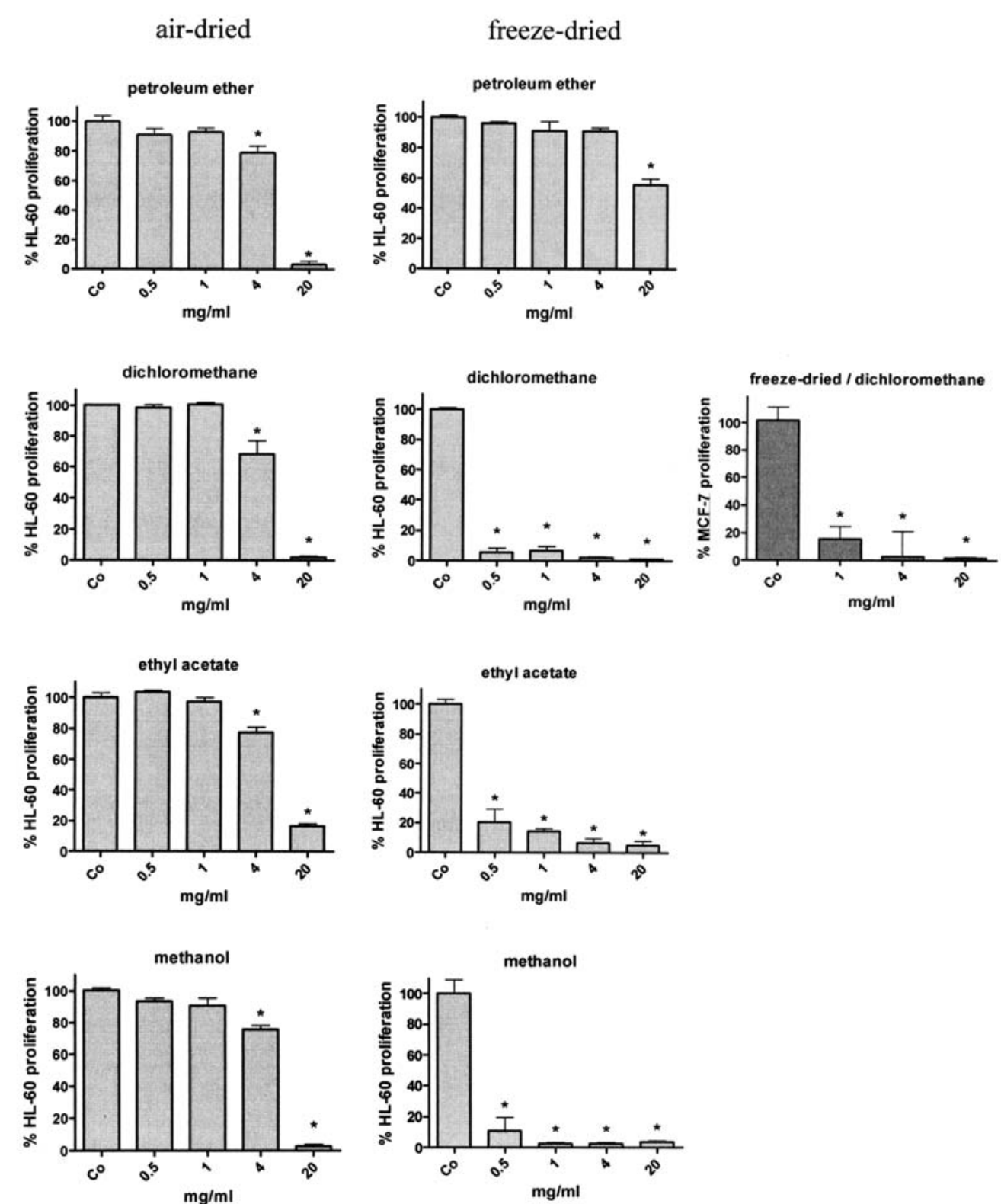

Figure 2. Anti-proliferative effect of A. schlechtendalii foliage and root extracts. HL-60 cells (seeded into T-25 flasks at 1x105 cells/ml density) and MCF-7 cells (seeded into 24-well plates at $1 \times 10^{4}$ cells $/ \mathrm{ml}$ density) were grown to enter logarithmic growth phase, and incubated with the indicated extracts (petrol ether, dichloromethane, ethyl acetate and methanol) from 0.5, 1, 4 and $20 \mathrm{mg} / \mathrm{ml}$ dried (a) foliage and (b) roots (both air-dried and freeze-dried). Cells were counted after 24, 48 and $72 \mathrm{~h}$ of treatment and the percentage of proliferation within this time span was calculated. Experiments were done in triplicate. Error bars indicate SEM, and asterisks significance $(\mathrm{p}<0.05)$

to $4 \mathrm{mg} / \mathrm{ml}$ roots) (Fig. 3). Nevertheless, inactivation of Cdc25A together with the suppression of the cell cycle regulator cyclin D1 within $8 \mathrm{~h}$ of treatment (both gene products are oncogenes and up-regulated in many cancer entities) was most likely the reason for cell cycle arrest. Cyclins are a family of proteins inducing and controlling mitosis by regulating the activity of cyclin dependent kinases (Cdks). In addition, expression of p21 was transiently induced (Fig. 3).

Analysis of inflammatory response. Since S. podophyllum and A. schlechtendalii are traditionally used as remedies to treat a wide spectrum of inflammations, the most active extract types were tested in vitro regarding their anti-inflammatory potential. Neither of the tested plant extracts showed inhibition in the CD62E-expression assay upon TNF $\alpha$ stimulation in HUVECs (11) or in a COX-2 inhibitor screening assay (from Cayman-Cat. No. 560131, which measures $\mathrm{PGF}_{2 \alpha}$ produced by $\mathrm{SnCl}_{2}$ reduction of COX-derived $\mathrm{PGH}_{2}$; data not shown). The MEK-Erk pathway is involved in mediating pro-inflammatory stimuli (12). Therefore, the activation of the MEKErk signaling pathway was investigated in response to the $A$. schlechtendalii root extract by using phospho-specific antibodies. Although $4 \mathrm{mg} / \mathrm{ml}$ extract rapidly and transiently induced Erk1/2 phosphorylation (reaching the maximum after $8 \mathrm{~h}$ and returning back to control level after $24 \mathrm{~h}$; MEK did not become activated) Erk1/2 and MEK protein levels were 
a

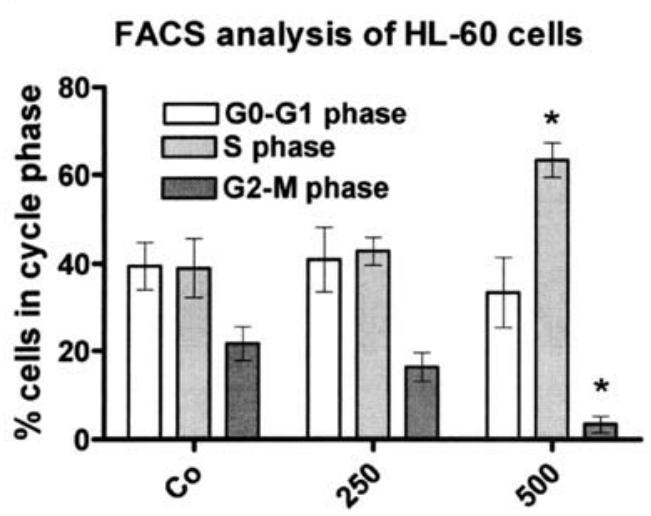

A. schlechtendalii

dichloromethane extract $(\mu \mathrm{g} / \mathrm{ml})$

b

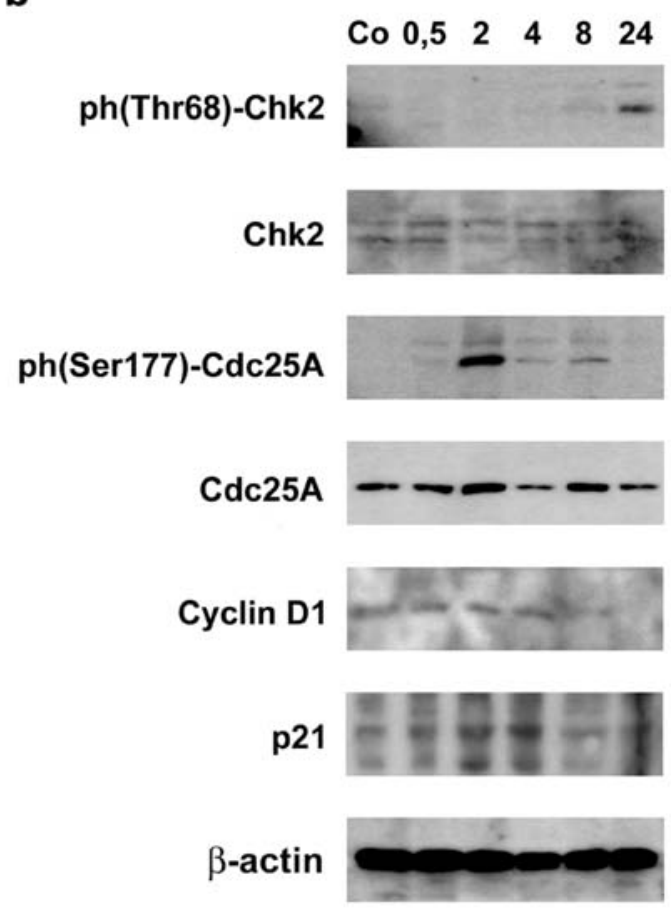

Figure 3. Effect of freeze-dried A. schlechtendalii root dichloromethane extract on the cell cycle. (a) HL-60 cells were treated with 1.75 and $3.5 \mu \mathrm{g} / \mathrm{ml}$ extract (corresponding to 250 and $500 \mu \mathrm{g} / \mathrm{ml}$ root) for $24 \mathrm{~h}$ and then subjected to FACS analysis to determine the cycle phase in which the cells accumulated. Error bars indicate SEM and asterisks significance $(\mathrm{p}<0.05)$. Experiments were done in triplicate. (b) HL-60 cells $\left(1 \times 10^{6}\right.$ cells) were seeded into T-75 tissue culture flasks and incubated with $27.9 \mu \mathrm{g} / \mathrm{ml}$ extract (corresponding to $4 \mathrm{mg} / \mathrm{ml}$ roots) for $0.5,2,4,8$ and $24 \mathrm{~h}$ and subjected to Western blot analysis using the indicated antibodies. Equal sample loading was controlled by Poinceau S staining and $\beta$-actin analysis.

reduced after 8 and 24 h, respectively (Fig. 4). The downregulation of the MEK and Erk protein levels may contribute to suppress inflammatory reactions caused i.e. by bacterial infections.

Induction of cell death. The most relevant property of anticancer agents is the potential to eliminate transformed cells. This can be achieved by various different ways but finally ends with the death of the cancer cell. Therefore, the proapoptotic properties of the A. schlechtendalii extract was

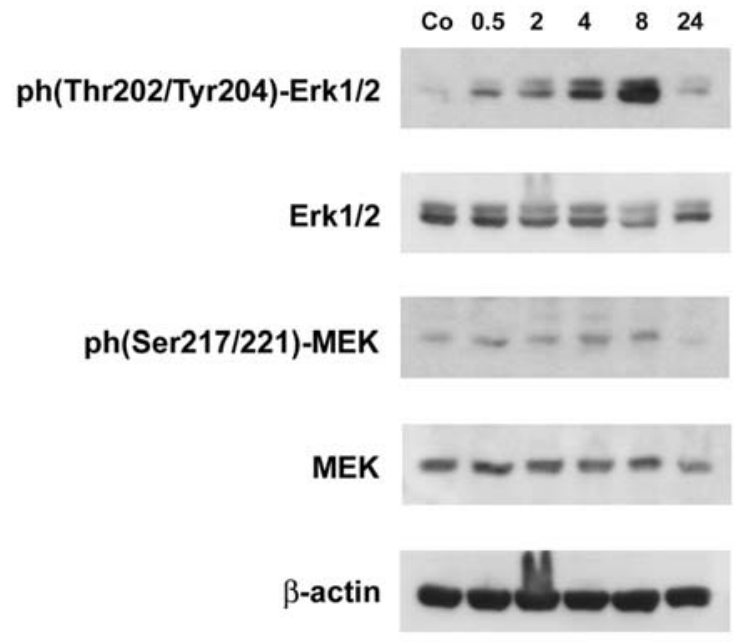

Figure 4. Analysis of Erk pro-inflammatory pathway. HL-60 cells ( $1 \times 10^{6}$ cells) were seeded into T-75 tissue culture flasks and incubated with $27.9 \mu \mathrm{g} / \mathrm{ml}$ extract (corresponding to $4 \mathrm{mg} / \mathrm{ml}$ roots) for $0.5,2,4,8$ and $24 \mathrm{~h}$ and subjected to Western blot analysis using the indicated antibodies. Equal sample loading was controlled by Poinceau S staining and $\beta$-actin analysis.

tested in HL-60 and MCF-7 cells. HL-60 and MCF-7 cells were exposed to increasing concentrations of extracts derived from air-dried foliage and freeze-dried roots. The root extract triggered a massive apoptotic response in both cell lines (Fig. 5b and d), which was confirmed by caspase 3 cleavage (activation), using a caspase 3 antibody, which detects only the activated form, but not holo-caspase 3 , and proteolytic signature-type degradation of PARP (Fig. 6a). The foliage extract also triggered apoptosis in HL-60 cells, however less effective than the root extract (Fig. 5a). Unexpectedly, the foliage extract provoked necrosis of MCF-7 cells (Fig. 5c) demonstrating that distinct bio-active components were contained in foliage and roots. Since necrosis-provoking properties are undesired during chemotherapeutic treatment (because of severe side effects) this extract type was neglected and only the root extract was further analysed.

Microtubules function as structural and mobile elements in mitosis. Mobility of the tubulin bundles is achieved by fine-tuned polymerizing and de-polymerizing events. Tilting tubulin dynamics is incompatible with functional cell division (13). Taxol, a major anti-cancer drug derived from the genus Taxa sp. (Pacific yew) (14), stabilises microtubules of cancer cells thereby causing mitotic arrest and in consequence apoptosis. Polymerised/stabilized microtubule $(15,16)$ are reflected by the increased acetylation of $\alpha$-tubulin at lysine 40 (17), and therefore, the detection of acetylated $\alpha$-tubulin is an indirect way of monitoring the polymerization status of tubulin. Exposure of HL-60 cells to A. schlechtendalii root extract for $2 \mathrm{~h}$ increased the acetylation of $\alpha$-tubulin and after 8 and $24 \mathrm{~h}$ tubulin became progressively degraded (Fig. 6a). This evidenced that this extract type contained tubulintargeting activity and was certainly responsible for the proapoptotic property.

\section{Discussion}

Although more than $60 \%$ of all pharmaceutical drugs that are used in the industrialised world are derived from natural 
a

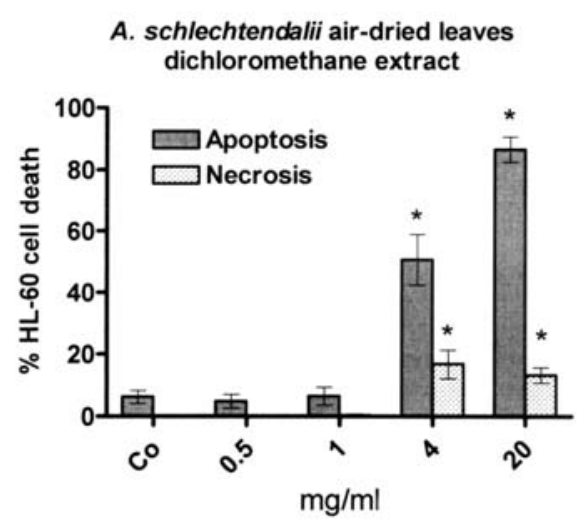

$\mathrm{c}$

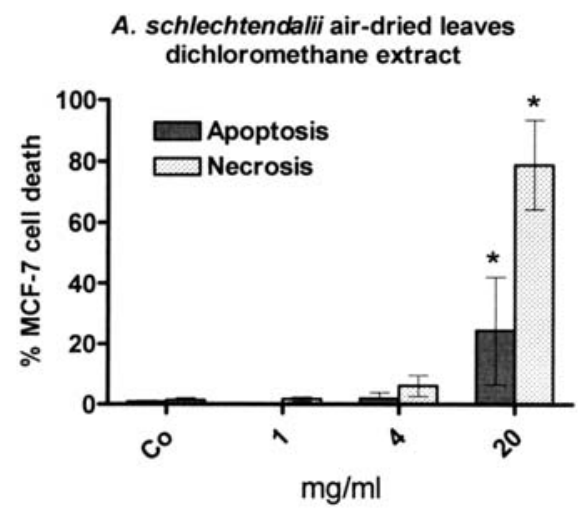

b

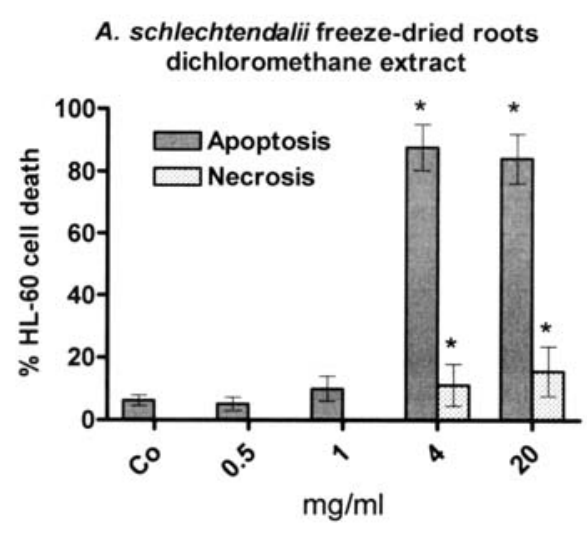

$\mathrm{d}$

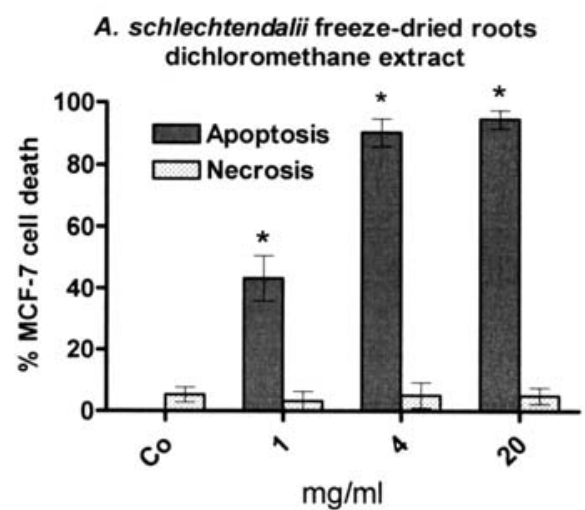

Figure 5. Induction of cell death. (a and b) HL-60 cells were treated for $72 \mathrm{~h}$ and (c and d) MCF-7 cells were treated for $96 \mathrm{~h}$ with increasing concentrations of the dichloromethane extracts derived from ( $\mathrm{a}$ and $\mathrm{c}$ ) air-dried leaves, and (b and d) freeze-dried roots of A. schlechtendalii and the type of the induced cell death was determined and quantified by Hoechst 33258 and propidium iodide double staining. Error bars indicate SEM and asterisks significance (p<0.05). Experiments were done in triplicate.

a

Caspase 3

PARP -

$\beta$-actin

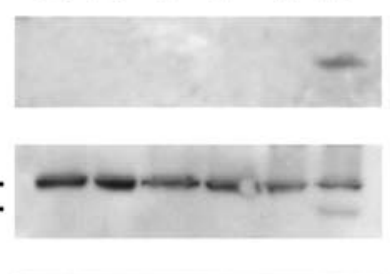

Co $\begin{array}{llllll}0.5 & 2 & 4 & 8 & 24\end{array}$

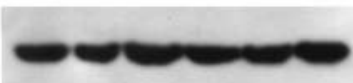

b acetylated
$\alpha$-tubulin

$\alpha$-tubulin

$\beta$-actin
Co $\begin{array}{llllll}0.5 & 2 & 4 & 8 & 24\end{array}$
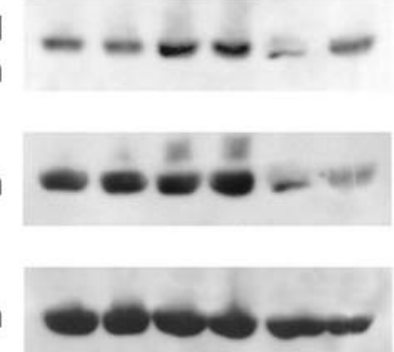

Figure 6. Effect of freeze-dried A. schlechtendalii root dichloromethane extract on apoptotic signalling. HL-60 cells (1x10 6 cells) were seeded into T-75 tissue culture flasks and incubated with $27.9 \mu \mathrm{g} / \mathrm{ml}$ extract (corresponding to $4 \mathrm{mg} / \mathrm{ml}$ roots) for $0.5,2,4,8$ and $24 \mathrm{~h}$ and subjected to Western blot analysis using (a) anti-caspase 3 and anti-PARP, and (b) anti-acetylated $\alpha$-tubulin and anti- $\alpha$-tubulin antibodies. Equal sample loading was controlled by Poinceau S staining and B-actin analysis.

products traditional remedies were widely ignored by Western medicine and pharmaceutical companies. Since the development of entirely new drugs is extremely expensive the investigation of traditional healing plants as medication against the typical diseases of modern civilisations, such as cancer, comes more frequently into focus of basic and translational research. We are interested in the knowledge of herbalists and curanderos/curanderas of very old cultures or civilizations living in high biodiversity regions still practising their traditional healing methods based on a rich botanical pharmacy. Therefore, the long lasting medicinal experience of the Maya is particularly precious, because some Maya populations still exist rather isolated for hundreds of years, and treat and heal diseases of many kinds using natural remedies from the neighbouring tropical rain forests, which are in Central America amongst the richest biodiversity areas in the world. In this investigation the criteria for plant selection were: i) the traditional use to treat chronic or severe 
inflammation and ii) the absence of records in Western medicinal- and patent databases.

The present work analysed the anti-cancer properties of two rainforest species of the Aracea family that are still used in the long lasting medicinal tradition of the Maya of Guatemala/Belize to treat arthritis, rheumatism, cough and severe skin conditions (2). Whereas the parasitic vine $S$. podophyllum showed only weak anti-proliferative activity in the methanol extract the dichloromethane extract of $A$. schlechtendalii roots prevented HL-60 and MCF-7 cell growth already at very low extract concentrations (1.7 and $4.1 \mu \mathrm{g} / \mathrm{ml}$, respectively). In A. schlechtendalii we observed a property that could be interpreted as anti-inflammatory, namely the partly downregulated constitutive Erk1/2 and MEK expression, because the LPS-triggered inflammatory response is mediated by Erk1/2 (12) and also influenza A virus propagation engages the MEK-Erk pathway (18), but neither of the two plant species abrogated the TNFa amplification loop (involving $\mathrm{NF}-\kappa \mathrm{B}$ ) or $\mathrm{COX}-2$ driven prostanoid generation (not shown).

The growth inhibitory effects of $A$. schlechtendalii correlated with the activation of $\mathrm{Chk} 2$ and the transient induction of $\mathrm{p} 21$, the inhibition and down-regulation of Cdc25A, and suppression of cyclin D1 level. Cdks control cell cycle transit and are positively regulated by cyclins and Cdc25A. Cdc25A and cyclin D1 are oncogenes that are frequently overexpressed in a variety of cancer entities. Such as cyclins promote cell cycle transition by associating and activating cyclin-dependent kinases, Cdks are negatively regulated by $\mathrm{p} 21$, which itself is a target of p53. Although HL-60 cells are p53 deficient (19), Western blot analysis showed an up-regulation of p21 until $4 \mathrm{~h}$ upon treatment with A. schlechtendalii root extract, and thereafter a return to control levels. Besides p53, also MEK-Erk1/2 were shown to up-regulate p21 $(20,21)$ and this could have been achieved by the observed activation of Erk1/2 within $30 \mathrm{~min}$ of treatment.

Altogether, this resulted in the accumulation and stalling of HL-60 cells in S-phase and depletion from G2/M. This G2/M depletion was most likely caused by acetylation and subsequent degradation of $\alpha$-tubulin, which is required for spindle-formation and proper segregation of chromosomes during mitosis and this may have stalled the cells in S-phase and prevented cell division (22). The tubulin targeting property of A. schlechtendalii root extract was likely also causal for apoptosis that was triggered at very high rate in HL-60 and MCF-7 cells, as measured by HOPI staining and confirmed by caspase 3 activation and signature-type cleavage of PARP. Caspase- 3 is one of the key executioners of apoptosis, as it is either partially or totally responsible for the proteolytic cleavage of many key proteins such as the nuclear enzyme poly (ADP-ribose) polymerase (PARP) (23). Interestingly, the air-dried foliage material induced predominantly necrosis in MCF-7 cells and this could be due to the fact that this cell line does not express caspase 3 (24) and that there are several distinct active principles present in the various extract types and plant parts.

The Aracea family encompasses more than 105 genera and Anthurium more than 600 species, which seem to be genetically rather homogeneous (25). Anthurium species were shown to contain antioxidants and phenolic constituents such as flavone glucosides (26), which could be responsible for the anti-inflammatory potential since antioxidants such as other radical scavengers (e.g. vitamins) protect cells from oxidative DNA damage, possess anti-inflammatory properties and have been shown to be cancer preventive (3). Current northern Peruvian traditional medicine (around the Andean Cordilliera) can be traced back to the Moche culture and scores more than 500 healing plants from which only two are Aracea (27). The Spanish name for A. schlechtendalii is 'Oja de Piedra', and a similar plant with the same habitus and habitat (growing as epiphyte) and the same name as $A$. schechtendalii exists in the Peruvian Amazonas. However, this plant does not seem to be part of the Andean medicinal tradition most likely because of the enormous distances through rough wilderness. As we could demonstrate, the bioactivity of $A$. schlechtendalii roots is very short-lived and will not withstand the long transport through tropical climate. Whether indigenous tribes of the Peruvian Amazon lowland who live very scattered and hidden and entirely different from Andean tribes, take also advantage of 'Oja de Piedra' escapes the knowledge of the authors.

\section{Acknowledgements}

We wish to thank Toni Jäger for preparing the figures. The study was supported by the Fonds for Innovative and Interdisciplinary Cancer Research to M.F.-S and G.K; and the Hochschuljubiläumsstiftung der Stadt Wien to G.K.

\section{References}

1. Cragg GM, Newman DJ and Yang SS: Natural product extracts of plant and marine origin having antileukemia potential. The NCI experience. J Nat Prod 69: 488-498, 2006.

2. Arvigo R and Balick M: Rainforest Remedies. Lotus Press Twin Lakes, WI, 1998

3. Ribeiro LR, Mantovani MS, Ribeiro DA and Salvadori DM: Brazilian natural dietary components (annatto, propolis and mushrooms) protecting against mutation and cancer. Hum Exp Toxicol 25: 267-272, 2006.

4. Rakoff-Nahoum S: Why cancer and inflammation? Yale J Biol Med 79: 123-130, 2006.

5. Federico A, Morgillo F, Tuccillo C, Ciardiello F and Loguercio C: Chronic inflammation and oxidative stress in human carcinogenesis. Int J Cancer 121: 2381-2386, 2007.

6. Hold GL and El-Omar ME: Genetic aspects of inflammation and cancer. Biochem J 410: 225-235, 2008.

7. Grusch M, Polgar D, Gfatter S, Leuhuber K, Huettenbrenner S, Leisser C, Fuhrmann G, Kassie F, Steinkellner H, Smid K, Peters GJ, Jayaram HN, Klepal W, Szekeres T, Knasmuller S and Krupitza G: Maintenance of ATP favours apoptosis over necrosis triggered by benzamide riboside. Cell Death Differ 9: $169-178,2002$.

8. Huettenbrenner S, Maier S, Leisser C, Polgar D, Strasser S Grusch M and Krupitza G: The evolution of cell death programs as prerequisites of multicellularity. Rev Mutat Res 543: 235-249, 2003.

9. Venditti JM, Wesley RA and Plowman J: Current NCI preclinical antitumor screening in vivo: results of tumor panel screening, 1976-1982, and future directions. Adv Pharmacol Chemother 20: 1-20, 1984

10. Weinstein JN, Myers TG, O'Connor PM, Friend SH, Fornace AJ Jr, Kohn KW, Fojo T, Bates SE, Rubinstein LV, Anderson NL, Buolamwini JK, van Osdol WW, Monks AP, Scudiero DA, Sausville EA, Zaharevitz DW, Bunow B, Viswanadhan VN, Johnson GS, Wittes RE and Paull KD: An information-intensive approach to the molecular pharmacology of cancer. Science 275: 343-349, 1997. 
11. Zhang JS, Nelson M, Wang L, Liu W, Qian CP, Shridhar V, Urrutia R and Smith DI: Identification and chromosomal localization of CTNNAL1, a novel protein homologous to alphacatenin. Genomics 54: 149-154, 1998.

12. Kaminska B: MAPK signaling pathways as molecular targets for anti-inflammatory therapy - from molecular mechanisms to therapeutic benefits. Biochim Biophys Acta 1754: 253-262, 2005.

13. Piperno G and Fuller M: Monoclonal antibodies specific for an acetylated form of alpha-tubulin recognize the antigen in cilia and flagella from a variety of organisms. J Cell Biol 101: 2085-2094, 1985.

14. Geney R, Sun L, Pera P, Bernacki RJ, Xia S, Horwitz SB, Simmerling CL and Ojima I: Use of the tubulin bound paclitaxe conformation for structure-based rational drug design. Chem Biol 12: 339-348, 2005.

15. Marcus AI, Zhou J, O'Brate A, Hamel E, Wong J, Nivens M, El-Naggar A, Yao TP, Khuri FR and Giannakakou P: The synergistic combination of the farnesyl transferase inhibitor lonafarnib and paclitaxel enhances tubulin acetylation and requires a functional tubulin deacetylase. Cancer Res 65: 3883-3893, 2005.

16. Wilson PJ and Forer A: Effects of nanomolar taxol on crane-fly spermatocyte spindles indicate that acetylation of kinetochore microtubules can be used as a marker of poleward tubulin flux. Cell Motil Cytoskeleton 37: 20-32, 1997.

17. Piperno G, LeDizet M and Chang XJ: Microtubules containing acetylated alpha-tubulin in mammalian cells in culture. J Cell Biol 104: 289-302, 1987

18. Pleschka S, Wolff T, Ehrhardt C, Hobom G, Planz O, Rapp UR and Ludwig S: Influenza virus propagation is impaired by inhibition of the Raf/MEK/ERK signalling cascade. Nat Cell Biol 3: 31-35, 2001
19. Biroccio A, Del Bufalo D, Ricca A, D'Angelo C, D'Orazi G, Sacchi A, Soddu S and Zupi G: Increase of BCNU sensitivity by wt-p53 gene therapy in glioblastoma lines depends on the administration schedule. Gene Ther 6: 1064-1072, 1999.

20. Park KS, Jeon SH, Oh JW and Choi KY: p21Cip/WAF1 activation is an important factor for the ERK pathway dependent anti-proliferation of colorectal cancer cells. Exp Mol Med 36: 557-562, 2004.

21. Facchinetti MM, De Siervi A, Toskos D and Senderowicz AM: $\mathrm{UCN}-01$-induced cell cycle arrest requires the transcriptional induction of $\mathrm{p} 21$ (waf1/cip1) by activation of mitogen-activated protein/extracellular signal-regulated kinase kinase/extracellular signal-regulated kinase pathway. Cancer Res 64: 3629-3637, 2004.

22. Bolsover SR, Hyams JS, Shephard EA, White HA an Wiedemann CG: Cell biology: a short course. John Wiley \& Sons Inc., Hoboken, New Jersey, 2004

23. Fernandes-Alnemri T, Litwack G and Alnemri ES: CPP32, a novel human apoptotic protein with homology to Caenorhabditis elegans cell death protein Ced-3 and mammalian interleukin-1 beta-converting enzyme. J Biol Chem 269: 30761-30764, 1994.

24. Hu CC, Tang $\mathrm{CH}$ and Wang JJ: Caspase activation in response to cytotoxic Rana catesbeiana ribonuclease in MCF-7 cells. FEBS Lett 503: 65-68, 2001.

25. Mohamed TR, Khalifa SF and El-Dine RMS: Leaf protein electrophoretic profiles and chromosome numbers of some Aracea. Int J Agricult Biol 8: 231-234, 2006

26. Aquino R, Morelli S, Lauro MR, Abdo S, Saija A and Tomaino A: Phenolic constituents and antioxidant activity of an extract of Anthurium versicolor leaves. J Nat Prod 64: 1019-1023, 2001

27. Bussman RW and Sharon D: Traditional medicinal plant use in Northern Peru: tracking two thousand years of healing culture. J Ethnobiol Ethnomed 2: 1-18, 2006 